\title{
An Examination of the Congruency between the University Teacher Training Contents and Secondary School Contents in Tanzania: The Case of Sokoine University of Agriculture
}

\author{
Sotco Claudius Komba ${ }^{1} \&$ Sarah Vincent Chiwamba ${ }^{2}$ \\ ${ }^{1}$ Department of Social Sciences, Sokoine University of Agriculture, Chuo Kikuu, Morogoro, Tanzania \\ ${ }^{2}$ Department of Education, Sokoine University of Agriculture, Chuo Kikuu, Morogoro, Tanzania \\ Correspondence: Sotco Claudius Komba, Department of Social Sciences, Sokoine University of Agriculture, P.O. \\ BOX 3038, Chuo Kikuu, Morogoro, Tanzania. E-mail: sotratz@yahoo.com
}

Received: January 20, 2016

Accepted: March 4, 2016

Online Published: March 15, 2016

doi:10.5539/jel.v5n2p100

URL: http://dx.doi.org/10.5539/jel.v5n2p100

\begin{abstract}
It is ideally expected that after student teachers have gone through comprehensive curricula contents, they should possess the necessary competences and skills to enable them deliver effectively as teachers. However, some student teachers in Tanzania have expressed their concerns that some of the contents found in the curricula for teacher training programmes do not link with the contents taught in secondary schools. Therefore, this study was designed to examine the congruency between the contents student teachers cover during their studies at Sokoine University of Agriculture (SUA), one of the Tanzanian teacher training institutions, and contents taught in Tanzanian secondary schools. The study involved a randomly obtained sample of 181 third year students, pursuing various teacher education degree programmes. The study adopted a cross-sectional research design in which a set of questionnaire, which consisted of both open and closed-ended questions, was administered to the sampled respondents. The collected data were analyzed using SPSS in which frequencies and percentages of responses to the questions presented in the questionnaire were computed to answer research questions advanced for this study. The findings were as follows: First, the majority $(66.9 \%)$ of student teachers felt that there was a congruency between the University contents and secondary school contents and about one third (33.1\%) of student teachers felt that the congruency did not exist. Secondly, the majority (95\%) of student teachers felt that the contents of education courses taught at the University were applicable in real school situations and the minority (5\%) did not feel so. Third, the majority $(91.7 \%)$ of student teachers felt that the teacher training programmes offered at SUA had enabled them to acquire sufficient classroom teaching skills and basic theories in education. Fourth, some challenges facing teacher training programmes offered at SUA, as reported by the respondents, included irrelevant contents in some university courses, inadequate infrastructures, and lack of opportunities for practice, to mention but a few. Based on these findings, it is recommended that whenever an opportunity to review the existing teacher training programmes comes, the exercise should be preceded with needs analysis to help determine if the existing programmes adequately address the needs of the teaching profession for which the student teachers are being prepared.
\end{abstract}

Keywords: congruency, teacher training contents, secondary school contents, Tanzania

\section{Introduction}

There is a general consensus that teachers are the cornerstone for the successful provision of quality education in any given country. Following the implementation of Secondary Education Development Programme (SEDP) in Tanzania, in which one of the objectives was to increase student enrollment in secondary schools, the demand for teachers increased. Universities and teacher training colleges responded to this demand by increasing enrollment of students in teacher training programmes. The universities and other institutions which did not have the tradition of offering such programmes, established the same to join hands with the government in the efforts to increase the number of teachers in secondary schools.

Sokoine University of Agriculture (SUA) is one of the universities in Tanzania which did not have education degree programmes. In support of the government's efforts to increase the number of teachers in secondary schools, SUA established education degree programmes in 2008 and the first intake of student teachers 
graduated in 2011. Currently, there are six education degree programmes at SUA in which students specialize in the following combinations of science teaching subjects: Chemistry and Biology, Chemistry and Mathematics, Geography and Biology, Geography and Mathematics, Informatics and Mathematics, and Agricultural Science and Biology. In addition to the teaching (content) subjects which provide student teachers with hard skills, the teacher training curricula in use include professional and general courses as well which are anticipated to enhance student teachers' soft skills. The professional courses include educational psychology, educational measurement and evaluation, educational research, educational management and administration, philosophy of education, sociology of education, curriculum development and evaluation, and the like. On the other hand, the general courses include communication skills, computer applications, and entrepreneurial skills. The duration for each of the education degree programme is 3 years and all student teachers are supposed to do an eight week supervised Teaching Practice (TP) each year, as an integral part of their teacher training programmes. Teaching Practice is pertinent as it serves the following purposes: First, it offers student teachers with experiences through participation and observation. This is done under the auspices of both SUA and the schools to which the student teachers are attached. Secondly, TP is designed to equip the student teachers with professional skills through both planned and unplanned programmes of the schools where they are posted. In other words, TP is a practical opportunity which complements the theoretical aspects of the teaching profession covered during lectures at the University.

It is expected that after student teachers have gone through such comprehensive curricula, they should possess the necessary competences and skills to enable them deliver effectively as teachers. However, the situation on the ground seems to be contrary to these expectations. There have been concerns by some student teachers that some of the contents of teaching subjects found in the curricula for teacher training programmes at SUA have no link with the contents of the subjects taught in secondary schools. In addition, experiences gained during the supervision of TP has revealed that some student teachers shy away from teaching some topics in their subjects of specialization when they are assigned to do so. The advanced reasons for avoiding some topics include lack of both knowledge and skills required in teaching such topics.

This study was designed to examine whether there is congruency between the contents student teachers cover during their studies at the university and the contents taught in Tanzanian secondary schools. The study was specifically conducted to seek answers to the following questions:

i. To what extent do contents in the subjects of specialization taught at the University reflect the contents taught in secondary schools?

ii. To what extent are contents of education courses taught at the University applicable by student teachers in real school situations?

iii. To what extent do student teachers feel that the teacher training programmes offered at SUA enable them to acquire sufficient classroom teaching skills and basic theories in education?

iv. What should be done in order to improve the teacher training programmes at SUA?

This study was prompted by the fact that there has been no study conducted to examine the congruency between the contents taught at the university and the contents taught in secondary schools, since the establishment of education degree programmes at SUA in 2008. The study was based on the assumption that at the end of any teacher training programme, teachers must be knowledgeable in both what and how they are to teach.

\section{Literature Review}

Education is the key to the development agenda of any nation. This is so because when people of a given nation are educated, it is easy for them to get mobilized and involved in the national development process. However, it is worth noting that not any education that is provided aids in bringing about development in the respective nations. The national development process is essentially dependent upon the provision of quality education to all people involved in the process. In other words, if the provided education is of low quality or irrelevant to the national development process, it becomes difficult for a given nation to have her development goals realized. The quality of education depends on a number of factors. However, in this article, we will focus on two important aspects: curricula in use and the type of teachers being trained to implement all instructional activities implied in the school curricula.

Tanzania follows a centralized system of curriculum development. All schools in the country, including secondary schools, use the same curriculum issued by the then Ministry of Education and Vocational Training (MoEVT), now Ministry of Education, Science, Technology and Vocational Training. In the universities, the curricula in use are developed within the universities. For example, if a new degree programme (i.e., a degree 
programme not found in any other university within the country) has to be established, subject specialists usually decide on the contents of the programme and at a later stage, some stakeholders are consulted to provide inputs on the developed programme curriculum. Thereafter, the curriculum document is taken to the Tanzania Commission for Universities (TCU), for approval. If the degree programme sought to be established in a given university is also offered by another university within the country, the common approach has been that of "copying and pasting" of contents from the existing curriculum found elsewhere within the country. Then, the compiled curriculum document is taken to the Tanzania Commission for Universities (TCU), for approval. What is common in both cases is that students, who are consumers of the curricula contents, are not effectively involved in the process of developing curricula for different degree programmes offered by the universities. If at all they are invited to participate in discussing contents of the developed curricula, their representation is usually very limited. As if that is not enough, even the process of curricula review in the universities which is supposed to take place every after three years, is not effectively carried out since the process is largely conducted for procedural requirements (i.e., not involving significant review of strengths and weaknesses of the curricula, especially from stakeholders' point of view). In addition, what seems to be a challenge is that some curricula contents for degree programmes offered by the universities do not seem to have relevance with the activities in which graduates get involved after graduation.

Nevertheless, it is important to acknowledge the fact that for secondary school teachers to be effective, a strong foundation on the subjects taught (i.e., subject matter knowledge) is mandatory. This can only be achieved if the curricula used in training them are comprehensive and have a link with what is taught in schools. When the curricula exhibit some deficiencies, it becomes difficult to produce quality teachers, hence affecting negatively the provision of quality education. According to Miguel and Barsaga (1997), when considering factors affecting students' performance, the teacher is always the key factor. The same view is also supported by Kane, Rockoff, and Staiger (2007) who point out that skilled teachers are one of the single most important influences on student and that other salient variables do not impact students' learning as much as the quality of their teachers.

A study conducted by Anakwue (1997) found, among others, that Mathematics teacher training programme contents in Nigeria appeared not to be related to the subject matter of school mathematics nor to the needs of trainees. In the same study, it was also revealed that the majority of newly qualified teachers in Nigeria could not be relied upon to teach the subject matter of the Nigerian National Mathematics Curriculum (especially the geometry and trigonometry components) with confidence. This was despite the fact that the teachers had pursued a teacher training programme for some years which implied lack of relationship between the university teacher training curriculum and the school subject matter. A similar study was also conducted by Otaala, Maani and Bakaira (2013) in which the main objective was to examine the effectiveness of the Kyambogo University teacher-education curriculum on secondary school teacher performance in Uganda. The findings were contrary to Anakwue's as it was revealed that both academic and pedagogical contents covered at the university enabled them teach competently in secondary schools, implying the existence of relationship between the university teacher training curriculum and the school subject matter. However, student teachers raised a concern that they experienced heavy course load (i.e., professional courses, academic (teaching) subject courses and school practice) at the university and suggested reduction of courses or extension of the teacher training duration from three to four years.

Literature indicates that an effective teacher needs two kinds of knowledge which enable them make appropriate decisions in teaching. These include subject matter (or content) knowledge and pedagogical knowledge (Otaala, Maani, \& Bakaira, 2013; Anakwue, 1997). The subject matter or content knowledge is the teacher's understanding of the subject she/he teaches. According to Wilson and Winberg (1988), the depth and organization of this knowledge influences how teachers structure and teach lessons. On the other hand, pedagogical knowledge can be conceived as the knowledge of teaching and learning theories, principles, and processes that cut across disciplines (Reynolds \& Strom, 1988). Gudmundsdottir (1987), as cited in Auseon (1995), further argues that it is also the skill in the use of teaching methods and strategies that are not subject-specific. The two kinds of teachers' knowledge are considered as pivots upon which successful teaching oscillates. This implies that when university curricula for teacher training programmes are being prepared, the contents should reflect the two kinds of knowledge.

The ministries responsible for communication, science and technology are currently developing a roadmap to achieve Tanzania's quest for prosperity in Science Technology and Innovation Reform by implementing innovative programmes (URT, 2014). This initiative has been prompted by the fact that every great revolution is closely linked with some transformative breakthroughs in science and technology which have a far reaching impact on the rise or fall of a nation and the destiny of the country as well. In order to make such a reform 
successful, universities and other training institutions must review their curricula to have contents which are responsive to the needs of the nation as per the developed reform roadmap. In addition, teaching approaches need to change at all levels of education so that the focus becomes what learners can be able to do after a course of study rather than what they can just be able to remember. In other words, the focus should be on skills and competences. For all these to be realized, two important things need to be considered: availability of well trained teachers who can be able to facilitate learning and promote inquisitive minds among the learners and curricula which are responsive to diverse societal needs.

Sokoine University of Agriculture, which trains science teachers to teach in secondary schools, has been striving to produce quality teachers to teach science subjects in Tanzanian secondary schools. It is expected that the graduates will complement the governments' efforts to affect Science Technology and Innovation Reform in the country. However, as pointed out earlier in this article, some concerns have been raised by student teachers that some of the contents of teaching subjects found in the curricula for teacher training programmes at SUA have no link with the contents of the subjects taught in secondary schools. Since the programmes have been offered for some years and no study has been conducted to examine the congruency between the contents taught at the university and the contents taught in secondary schools, this study was designed to shed light to the observed knowledge gap.

\section{Methodology}

This study sought to examine the congruency between the university teacher training contents and secondary school contents in Tanzania. The study was conducted at Sokoine University of Agriculture, involving a randomly obtained sample of 181 third year students, pursuing various education degree programmes. The study adopted a cross-sectional research design in which a set of questionnaire, which consisted of both open and closed-ended questions, was administered to the sampled respondents. The questions focused on the relevance of contents found in the university teacher training curricula and the extent to which the contents reflected the contents of subjects taught in secondary schools. In addition, the questionnaire comprised some questions which sought to elicit responses from the respondents on what should be done to improve the training of teachers at Sokoine University of Agriculture. It is worth noting that all education degree programmes at SUA last for three years and, as pointed out earlier, all student teachers undertake a supervised Teaching Practice each year in order to interact with real school environment. In view of this, third year students who were in their last year of study were involved in this study because they were considered to have adequate teaching experience compared with the first or second year students. The collected data were analyzed using SPSS in which frequencies and percentages of responses to the questions presented in the questionnaire were computed to answer research questions advanced for this study.

\section{Findings of the Study}

This study sought to answer four research questions as pointed out in the introduction section of the article. The findings are presented according to themes generated from the research questions as follows:

\subsection{Congruency between University Contents and Secondary School Contents}

One of the research questions advanced for this study sought to elicit responses from the respondents on whether or not the contents in the subjects of specialization taught at the University reflected the contents taught in secondary schools. On this aspect, the respondents were asked two questions: the first question required students to either agree or disagree whether the contents of their teaching subjects covered at the University reflected the contents taught in secondary schools. The responses on this question were as presented in Table 1:

Table 1. University contents versus secondary school contents $(\mathrm{N}=181)$

\begin{tabular}{|c|c|c|}
\hline \multirow[b]{2}{*}{ Question } & \multicolumn{2}{|c|}{ Response } \\
\hline & Yes & No \\
\hline Do contents of your teaching subjects reflect the contents taught in secondary se & $\begin{array}{c}121 \\
(66.9 \%) \\
\end{array}$ & $\begin{array}{c}60 \\
(33.1 \%) \\
\end{array}$ \\
\hline
\end{tabular}

Table 1 indicates that $66.9 \%$ of all respondents agreed that the contents of their teaching subjects covered at the University reflected the contents taught in secondary schools and $33.1 \%$ disagreed. This implies that the majority of respondents felt that there was a congruency between University contents and secondary school contents and more than one third of the respondents felt that the congruency did not exist. 
The second question required students to give reasons for either agreeing or disagreeing that the contents of their teaching subjects covered at the University reflected the contents taught in secondary schools. The responses were as shown in Table 2:

Table 2. Reasons for either agreeing or disagreeing $(\mathrm{N}=181)$

\begin{tabular}{llcc}
\hline S/N & Reasons for Agreeing & Frequency & Percentage \\
\hline 1 & Contents are linked with contents found in secondary school syllabi & 108 & 59.7 \\
2 & Contents enable student teachers become flexible in teaching & 12 & 6.6 \\
\hline & Reasons for Disagreeing & & \\
\hline 1 & Some university contents are irrelevant and inapplicable & 51 & 28.2 \\
2 & University course contents are too theoretical & 10 & 5.5 \\
\hline
\end{tabular}

As shown in Table 2, some reasons were provided by respondents for either agreeing or disagreeing that the contents of teaching subjects covered at the University reflected the contents taught in secondary schools. For the respondents who agreed, the main reasons were two: Firstly, the respondents stated that the contents are linked with contents found in secondary school syllabi, which was reported by $59.7 \%$ of all respondents. Secondly, $6.6 \%$ of the respondents indicated that contents of teaching subjects covered at the University enabled them become flexible in the course of teaching.

With regard to respondents who disagreed, two reasons were given: Firstly, some contents were irrelevant and inapplicable, which was reported by $28.2 \%$ of the respondents. Secondly, $5.5 \%$ of respondents stated that some University course contents were too theoretical.

\subsection{Applicability of University Education Courses in Real School Situations}

The second research question sought to elicit responses on the extent to which contents of education courses taught at the University were applicable by student teachers in real school situations. On this aspect, the respondents were once again asked two questions: The first question required student teachers to either agree or disagree whether the contents of education courses (i.e., educational psychology, educational measurement and evaluation, educational research, educational management and administration, philosophy of education, sociology of education, curriculum development and evaluation etc.) taught at the University were applicable by student teachers in real school situations. The responses on this question were as presented in Table 3.

Table 3. Applicability of the university contents of education courses

\begin{tabular}{lcc}
\hline & \multicolumn{2}{c}{ Response } \\
\cline { 2 - 3 } Question & Yes & No \\
\hline Are the contents of education courses applicable in real school situations? & 172 & 9 \\
& $(95 \%)$ & $(5 \%)$ \\
\hline
\end{tabular}

Table 3 indicates that $95 \%$ of all respondents agreed that the contents of education courses taught at the University were applicable by student teachers in real school situations and $5 \%$ disagreed. It means that the majority of respondents felt that the contents of education courses taught at the University were applicable in real school situations and the minority did not feel so.

The second question required students to give reasons for either agreeing or disagreeing that the contents of education courses taught at the University were applicable by student teachers in real school situations. The responses were as shown in Table 4: 
Table 4. Reasons for either agreeing or disagreeing $(\mathrm{N}=181)$

\begin{tabular}{lcc}
\hline Reasons for Agreeing & Frequency & Percentage \\
\hline Contents are helpful in acquisition of conflict resolution skills & 20 & 12 \\
Contents are helpful in managing classrooms and schools & 83 & 50.1 \\
Contents are helpful in preparing lessons/evaluation activities & 30 & 18.1 \\
Contents are helpful in professional development & 35 & 21.1 \\
Contents are helpful in understanding student behaviors & 89 & 53.7 \\
Contents are helpful in the acquisition of teaching skills & 34 & 20.5 \\
\hline Reasons for Disagreeing & & \\
\hline Contents are too large and some of them inapplicable & 5 & 3.1 \\
No opportunity for practice in some courses & 3 & 1.8 \\
Contents do not provide sufficient knowledge in teaching skills & 1 & 0.3 \\
\hline
\end{tabular}

As shown in Table 4, the majority of respondents gave six main reasons for agreeing that the contents of education courses taught at the University were applicable in real school situations. The leading reason was that contents were helpful in understanding student behaviors, which was indicated by $53.7 \%$ of the respondents. This was followed by another reason that contents were helpful in managing classrooms and schools in general, which was reported by $50.1 \%$ of the respondents. The contents being helpful in professional development and also in the acquisition of teaching skills were other reasons which were reported by $21.1 \%$ and $20.5 \%$ of the respondents respectively. Some respondents $(18.1 \%)$ indicated that the contents were helpful in preparing lessons/evaluation activities during teaching. The other reason was that contents were helpful in the acquisition of conflict resolution skills, which was reported by $12 \%$ of the respondents. Therefore, based on these findings, it seemed that the majority of the respondents were very positive on the applicability of university education courses in real school situations.

Regarding respondents who disagreed, it is worth noting that only the minority of the respondents indicated three reasons for disagreeing that the contents of education courses taught at the University were applicable by student teachers in real school situations. The reasons included the following: Contents are too large and some of them inapplicable (3.1\%); no opportunity for practice in some education courses $(1.8 \%)$; and contents do not provide sufficient knowledge in teaching skills (0.3\%).

\subsection{Teacher Training Programmes and Student Teachers' Acquisition of Classroom Teaching Skills and Basic Theories in Education}

The third research question focused on the extent to which student teachers felt that the teacher training programmes offered at the University had enabled them acquire sufficient classroom teaching skills and basic theories in education. The responses on this aspect were as presented in Table 5:

Table 5. Student teachers' feelings on the effectiveness of teacher training programmes $(\mathrm{N}=181)$

\begin{tabular}{|c|c|c|c|}
\hline Response & Reason & Frequency & Percentage \\
\hline \multirow{6}{*}{$\begin{array}{l}\text { Acquired sufficient classroom } \\
\text { teaching skills and basic } \\
\text { theories in education }\end{array}$} & Acquired lesson preparation skills & 85 & 47.0 \\
\hline & Acquired school management skills & 30 & 16.5 \\
\hline & $\begin{array}{l}\text { Acquired subject matter delivery/teaching } \\
\text { skills }\end{array}$ & 26 & 14.4 \\
\hline & $\begin{array}{l}\text { Acquired problem - solving skills relevant in } \\
\text { education contexts }\end{array}$ & 15 & 8.3 \\
\hline & Acquired student evaluation skills & 10 & 5.5 \\
\hline & Total & 166 & 91.7 \\
\hline \multirow{4}{*}{$\begin{array}{l}\text { Not acquired sufficient } \\
\text { classroom teaching skills and } \\
\text { basic theories in education }\end{array}$} & Irrelevant contents in some teaching subjects & 9 & 4.9 \\
\hline & Too much content with limited time & 3 & 1.7 \\
\hline & Inadequate opportunities for practice & 3 & 1.7 \\
\hline & Total & 15 & 8.3 \\
\hline
\end{tabular}


Table 5 indicates student teachers' feelings on the effectiveness of teacher training programmes. First of all, the majority of student teachers $(91.7 \%)$ felt that the teacher training programmes offered at SUA had enabled them acquire sufficient classroom teaching skills and basic theories in education. In their responses student teachers indicated the following specific skills they had acquired during their training: lesson preparation skills (46.9\%); school management skills (16.6\%); subject matter delivery/teaching skills (14.4\%); problem-solving skills (8.3\%); and student evaluation skills (5.5\%).

Nevetheless, the minority of respondents $(8.3 \%)$ reported that teacher training programmes offered at SUA had not enabled them acquire sufficient classroom teaching skills and basic theories in education. When they were asked to explain why they felt so, the main responses were as follows: irrelevant contents in some teaching subjects (4.9\%); too much content with limited time (1.7\%); and inadequate opportunities for practice (1.7\%).

\subsection{Suggestions for Improving Teacher Training Programmes from Students Perspectives}

The last research question sought to elicit responses from students on how best the teacher training programmes offered at SUA could be improved. The responses were as shown in Table 6.

Table 6. Suggestions for improving teacher training programmes at SUA $(\mathrm{N}=181)$

\begin{tabular}{llcc}
\hline S/N & Suggestions for Improving the training of teachers at SUA & Frequency & Percentage \\
\hline 1 & Increase number of lecture rooms to reduce overcrowding in classrooms & 7 & 3.9 \\
2 & Increase opportunities for practice to improve confidence & 45 & 24.9 \\
3 & Remove course contents which do not link with secondary school contents & 54 & 29.8 \\
4 & Improve assessment procedures & 9 & 5 \\
5 & Give equal weight in terms of time to both theory and practical sessions & 6 & 3.3 \\
6 & Use student-centered teaching approaches (e.g., seminar presentations) & 31 & 17.1 \\
7 & Allocate more lecture hours for education courses & 17 & 9.4 \\
8 & Improve infrastructures, such as classrooms & 12 & 6.6 \\
\hline
\end{tabular}

Table 6 indicates student teachers' suggestions for improving teacher training programmes at SUA. As it can be seen, a significant proportion of students $(29.8 \%)$ were concerned with university contents which do not link with secondary school contents. On this aspect, student teachers suggested removing such contents after conducting a study to establish contents which are applicable and those inapplicable in secondary school teaching. The other suggestion has got to do with opportunities for practice. Student teachers reported that there were limited time/opportunities for practicing what they had learned in classrooms. In this light, $24.9 \%$ of student teachers suggested to increase opportunities for practice to improve confidence. It was also suggested that university lecturers should use student-centered teaching approaches. This was stated by $17.1 \%$ of all respondents. Other suggestions included the following: Allocate more lecture hours for education courses $(9.4 \%)$; improve infrastructures, such as classrooms (6.6\%); improve assessment procedures (5\%); Increase number of lecture rooms to reduce overcrowding in classrooms (3.9\%); give equal weight in terms of time to both theory and practical sessions (3.3\%)

\section{Discussion of the Findings}

There is a general consensus that education plays a significant role in the development of any nation. This is because it is easier to mobilize educated people to take part in the national development process than those who are not educated. Through education, people acquire knowledge, skills and attitudes which enable them contribute significantly in development activities.

Teachers are the cornerstone in the provision of education and they can either hinder or facilitate learning. Therefore, for teachers to be effective, teacher training programmes ought to be designed such that they reflect goals and objectives which are responsive to the training and preparation needs of teachers to teach successfully and effectively. The goals can be divided into three categories i.e. teachers knowledge of content area, skills of teaching (both pedagogical and interpersonal) and teaching feelings and self-awareness (Anderson \& Minching, 1987). In the same light, some scholars (Otaala, Maani, \& Bakaira, 2013; Anakwue, 1997) divide the knowledge into two: Subject matter (or content) knowledge and pedagogical knowledge. When a teacher demonstrates an understanding of the subject matter she/he teaches, they are considered to have subject matter or content knowledge. Pedagogical knowledge is conceived in terms of knowledge of teaching and learning theories, principles, and processes that cut across disciplines. Therefore, when a teacher exhibits knowledge of learning 
theories, principles, and processes and applies them appropriately in different learning environment, she/he is considered to have adequate pedagogical knowledge. The two kinds of teachers' knowledge are considered as pivots upon which successful teaching oscillates.

In this study, it has been revealed that the majority $(66.9 \%)$ of all respondents agreed that the contents of their teaching subjects covered at the University reflected the contents taught in secondary schools and $33.2 \%$ of respondents felt that the congruency did not exist. The differences in perception might have been caused by the fact that, by the time this study was being conducted, SUA had six teacher education degree programmes in which student teachers specialize in different science teaching subjects. From students' responses, it seemed that, in some university courses, the congruency existed and in others, it did not exist. The findings that the congruency between the University contents and secondary school contents existed agree with those of Otaala, Maani and Bakaira (2013) who found that both academic and pedagogical contents covered at the university enabled teachers teach competently in secondary schools, implying the existence of relationship between the university teacher training curriculum and the school subject matter. On the other hand the findings that the congruency between University contents and secondary school contents did not exist agree with those of Anakwue (1997) who found, among others, that Mathematics teacher training programme contents in Nigeria appeared not to be related to the subject matter of school mathematics. The findings by Anakwue further revealed that the majority of newly qualified teachers in Nigeria could not be relied upon to teach the subject matter of the Nigerian National Mathematics Curriculum (especially the geometry and trigonometry components) with confidence. This implied lack of relationship between the university teacher training curriculum and the school subject matter.

This study has also found that the majority (95\%) of respondents felt that the contents of education courses taught at the University were applicable in real school situations. This seems to be logical because, as pointed out earlier in this article, teaching is essentially the process of making decisions. The pedagogical knowledge, which is acquired from education courses, is a significant tool in making appropriate decisions during teaching. Therefore, considering the importance of pedagogical knowledge, it seemed that the contents were well organized when curricula for these programmes were being developed and the majority of student teachers had ascribed high value to education contents. This is also supported by the findings of the third research question which revealed that the majority (91.7\%) of student teachers felt that the teacher training programmes offered at SUA had enabled them to acquire sufficient classroom teaching skills and basic theories in education.

However, this study has also revealed some challenges facing teacher training programmes offered at the University such as irrelevant contents in some courses, inadequate infrastructures, and lack of opportunities for practice, to mention but a few. While some of these challenges can be addressed at university level, others can be tackled in collaboration with other relevant organs. For example, the issue of removing irrelevant contents in some courses can be done at institutional level during curricula reviews so that what student teachers study at the university becomes applicable when they start teaching in schools.

\section{Conclusions and Recommendations}

The findings of this study have revealed that, to a great extent, a congruency between the contents student teachers cover during their studies at SUA and the contents taught in Tanzanian secondary schools exists. However, some student teachers feel that contents of some courses taught at the University do not have a link with what is taught in secondary schools, hence inapplicable. Based on these findings, it is recommended that whenever an opportunity to review the existing teacher training programmes comes, the exercise should be preceded with needs analysis to help determine if the existing programmes adequately address the needs of the teaching profession for which the student teachers are being prepared.

\section{References}

Anakwue, F. O. (1997). A study of training programmes for school mathematics teachers in Nigeria: Thesis submitted for PhD examination. Institute of Education, University of London, UK.

Anderson, L. W., \& Minching, B. (1987). Affective teacher education, the international encyclopedia of teacher education. USA: Pergamon Press Inc.

Auseon, J. (1995). The Role of Pedagogical and Subject Matter Knowledge in Preservice Art Teaching. Marilyn Zurmuehlin Working Papers in Art Education, 13, 54-68.

Gudmundsdottir, S. (1987). Pedagogical Content Knowledge: Teachers' Ways of Knowing. Paper presented at the annual meeting of the Amoncan Educational Research Association, New Orleans. 
Otaala, J., John S., Maani, \& Bakaira, G. G. (2013). Effectiveness of University Teacher Education Curriculum on the Secondary School Teacher Performance in Uganda: The Case of Kyambogo University. Journal of International Cooperation in Education, 15(3), 95-112.

Reynolds, M. C., \& Strom, S. M. (1988). Knowledge Bases for the Beginning Teacher. Paper presented at the February 20 Annual Meeting of the American Association for Colleges of Teacher Education, New Orleans, Louisiana.

Shahid, S. M. (2007). Teacher education in Pakistan (pp. 14-19). Majid Book Depot, Urdu Bazaar Lahore.

URT. (2014). Science technology and innovation: Reform roadmap highlights. Dar es Salaam, Tanzania: Ministry of Communication, Science and Technology.

Wilson, S. M., \& Wineburg, S. S. (1988). Peering at History Through Different Lenses: The Role of Disciplinary Perspectives in Teaching History. Teachers College Record, 89(4), 524-539.

\section{Copyrights}

Copyright for this article is retained by the author(s), with first publication rights granted to the journal.

This is an open-access article distributed under the terms and conditions of the Creative Commons Attribution license (http://creativecommons.org/licenses/by/3.0/). 